\title{
Levels and trends of the emerging contaminants HBCDs (hexabromocyclododecanes) and PFCs (perfluorinated compounds) in marine shellfish along French coasts
}

\author{
C. Munschy ${ }^{\mathrm{a}, *}$, P. Marchand ${ }^{\mathrm{b}}$, A. Venisseau ${ }^{\mathrm{b}}$, B. Veyrand ${ }^{\mathrm{b}}$, Z. Zendong ${ }^{\mathrm{b}}$
}

\author{
a IFREMER (Institut Français de Recherche pour l'Exploitation de la Mer), Laboratory of Biogeochemistry of \\ Organic Contaminants, Rue de l'lle d'Yeu, BP 21105, \\ 44311 Nantes Cedex 3, France \\ b LABERCA (LABoratoire d'Etude des Résidus et Contaminants dans les Aliments), ONIRIS Atlanpôle La \\ Chantrerie, BP 50707, 44307 Nantes, France \\ *: Corresponding author : Catherine Munschy, tel.: +33 (0)2 40374224 ; fax: +33 (0)2 40374075 ; email \\ address : cmunschy@ifremer.fr
}

\begin{abstract}
:
The levels and congener patterns of HBCDs (hexabromocyclododecanes) and PFCs (perfluorinated compounds) were determined in filter-feeding molluscs collected in 2008 and 2010 along the coasts of mainland France. $\alpha-H B C D$ and PFOS (perfluorooctane sulfonate) were detected in all samples, revealing widespread contamination of the coastal environment by these emerging contaminants. The spatial distribution of $\Sigma-H B C D$ concentrations showed higher median levels in samples from the Mediterranean Sea and English Channel respectively, i.e. $0.19 \mathrm{ng} \mathrm{g-1}$ wet weight (ww) and $0.08 \mathrm{ng} \mathrm{g}-1 \mathrm{ww}$, related to high anthropogenic pressure from urban and industrial activities, while the median concentration was $0.05 \mathrm{ng}$ g-1 ww in samples from the Atlantic coast. Among PFCs, PFOS was the only compound detected in all samples and PFDA (perfluorodecanoic acid) was the second most frequently-detected compound. PFOS median concentrations were $0.18 \mathrm{ng} \mathrm{g-1}$ ww, $0.09 \mathrm{ng} \mathrm{g}-1 \mathrm{ww}$ and $0.04 \mathrm{ng} \mathrm{g-1}$ ww in samples from the English Channel, the Atlantic coast and the Mediterranean coast respectively. The highest PFOS concentration was found in the Loire estuary, possibly related to local industrial activities. The Mediterranean samples showed a different pattern, with predominant long-chain PFCAs (perfluorocarboxylic acids), suggesting the presence of alternative sources on the Mediterranean coast.

The temporal trends studied in archived samples from the Seine estuary site showed a significant exponential increase in HBCD concentrations between 1981 and 2011, with a doubling time of 7 years, while PFOS levels underwent a significant linear decrease over time. These trends are coherent with current regulations on the use of these compounds. The results presented in this paper provide the first data on the contamination of the French coastal marine environment by the selected emerging compounds, and constitute a reference for the future monitoring of French coastal contamination by emerging contaminants.
\end{abstract}

\section{Highlights}

Levels and trends of HBCDs and PFCs were studied in the French coastal environment. Results show widespread contamination of shellfish by $\alpha-H B C D$ and PFOS. Contamination by $\alpha-H B C D$ increased exponentially between 1981 and 2011. PFOS levels underwent a significant linear decrease over time.

Keywords: Persistent organic pollutants ; Environment specimen banking ; Coastal marine environment ; Concentrations ; Patterns ; Temporal trends 


\section{Introduction}

Marine shellfish, and in particular filter-feeder bivalves, have been widely used to monitor chemical contamination of the coastal environment by Persistent Organic Pollutants (POPs), due to their broad geographical distribution, year-round availability and ability to bioaccumulate contaminants without extensively degrading them. These monitoring efforts, referred to as "Mussel Watch Programs", have been implemented in numerous countries worldwide (Beliaeff et al., 2002; O'Connor and Lauenstein, 2006; Ramu et al., 2007; Tanabe, 2008). Environmental specimen banking has been gaining interest since the 1960s and has now become a recognized approach for regular environmental monitoring. Nineteen Environmental Specimen Banks (ESB) currently exist on the 5 continents (Becker and Wise, 2010). In addition to the regular monitoring of historic contaminants, ESB samples can be used to monitor emerging compounds and conduct retrospective surveys (Johansson et al., 2006; Munschy et al., 2008; Esslinger et al., 2011: Kratzer et al., 2011; Reiner et al., 2011; Tanabe and Ramu, 2012). Time-series studies of emerging contaminants are important in order to assess variations in emissions, and evaluate the impact of legal restrictions on environmental levels. In this study, the target emerging contaminants were hexabromocyclododecanes (HBCDs) and perfluorinated compounds (PFCs). To our knowledge, data on the occurrence and trends of both classes of contaminant in France is very scarce, especially in relation to the coastal environment.

HBCD is mainly found in polystyrene insulation foam boards used for construction purposes, in textiles for upholstered furniture, and in electrical and electronic equipment and appliances (VECAP, 2009). World demand for HBCD has increased by nearly 32\% since 2001 and 
reached 22,000 tons in 2003, making it the third most widely-used brominated flame retardant (BFR) on a global scale, and the second in Europe (de Wit et al., 2010). No global controls on the production and use of HBCD have been reported to date (Lam et al., 2009), although voluntary reductions in emissions have been reported in Europe (Law et al., 2008a), and HBCD use has been banned in polystyrene building insulation under the European legislation REACH (Registration, Evaluation, Authorization and Restriction of Chemical substances) program since 2010 (Shaw et al., 2012).

Reportedly, HBCDs may be used as an alternative for polybrominated diphenyl ethers (PBDEs) in some applications following restrictions on the usage of penta- and octa-BDE commercial mixtures in Europe (Ramu et al., 2010; Ueno et al., 2010, Goscinny et al., 2011). HBCD recently came under consideration for inclusion in the Stockholm Convention POP list due to its persistency, bioaccumulative character, potent long-range atmospheric transport and toxicity (Marvin et al., 2011). HBCD presence has already been reported in various abiotic and biotic environmental matrices all over the world (Law et al., 2005; Covaci et al., 2006; Wu et al., 2012). Although commercial HBCD is mainly made up of $\gamma$-HBCD (75-89\%), plus lower amounts of the diastereoisomers alpha- and beta-HBCD (respectively 10-13\% and 112\%) (Covaci et al., 2006), alpha-HBCD is the main diastereoisomer found in biota samples due to its higher assimilation efficiency and/or slower degradation (Covaci et al., 2006; Haukås et al., 2010).

PFCs are widely used as surfactants in industrial and consumer products and as additives for fluoropolymer production (Ahrens, 2011). PFCs are extremely persistent, bioaccumulative and toxic, and globally distributed in the environment. Among this vast class of chemical 
products, the best known are perfluorosulfonates (PFSAs) and perfluorocarboxylic acids (PFCAs), of which perfluorooctane sulfonate (PFOS) and perfluorooctanoic acid (PFOA) are recognized as widespread in the environment (Giesy and Kannan, 2001; Martin et al., 2004; Nania et al., 2009; Houde et al., 2011). PFOS is often found to be the predominant compound in biota, whereas PFOA has a lower assimilation efficiency and half-life (Martin et al., 2003). PFOS has recently been included in the Stockholm Convention list of priority chemicals (UNEP, 2009). Despite the phase-out in long-chain PFCA production since 2000, many PFCs are still released into the environment through industrial and domestic activities and through the release and degradation of their precursors (Prevedouros et al., 2006; Wang et al., 2012). Waste Water Treatment Plants (WWTPs) and rivers are major pathways for their release into the aquatic environment (Bossi et al., 2008; Clara et al., 2008; Sánchez-Avila et al., 2010). However, data on their contamination levels in marine invertebrates and temporal trends remains scarce, especially in Europe. Nonetheless, seafood (fish and shellfish) is recognised as the primary dietary source of human exposure to PFCs (Falandysz et al., 2006; Haug et al., 2010).

This study aims to investigate the contamination levels and spatial distribution of HBCDs and PFCs in the French coastal marine environment and assess their temporal trends over the last 30 years. The samples (marine shellfish Mytilus edulis, Mytilus galloprovincialis, or Crassostrea gigas) were obtained from specimens collected in the framework of the French Mussel Watch Program (ROCCH -Réseau national d'Observation de la Contamination CHimique) operated by IFREMER since 1979. The study provides new results on the contamination of French coastal areas by emerging contaminants, thus filling the gaps as 
regards knowledge of the past and present occurrence of these compounds on a national scale. It also provides additional broad-interest data, aimed at increasing knowledge of the levels and temporal trends of emerging organohalogen contaminants in Europe. This work is a continuation of our previous study on polychlorinated biphenyls (PCBs), polychlorinated dibenzo-p-dioxins and dibenzofurans (PCDD/Fs) and PBDEs in marine shellfish (Johansson et al., 2006; Munschy et al., 2008).

\section{Materials and Methods}

\subsection{Sampling strategy}

The analysed samples were chosen from selected locations in the English Channel, Atlantic and along Mediterranean coasts, as shown in Fig. 1. These locations cover main estuaries and deltas (Seine, Loire, Gironde, Rhône), plus smaller tributaries. As no species-related differences in POP accumulation in oysters and mussels have been reported in the literature (Ueno et al., 2010), mussels (Mytilus edulis or Mytilus galloprovincialis) and oysters (Crassostrea gigas) were used indifferently to monitor HBCD and PFC contamination levels. HBCDs were analysed in samples collected in 2008 and 2010, while PFCs were analysed in samples collected in 2010. Samples obtained from IFREMER's ESB between 1981 and 2011 were used for the temporal trend study.

The shellfish were collected and handled in accordance with international guidelines for the monitoring of contaminants in biota (OSPAR, 2009). In order to avoid possible differences in contaminant concentrations due to seasonal factors affecting the physiological state of the shellfish (i.e., spawning), all samples were collected in the same manner and at the same time 
of year (from late November to early December). In order to reduce inter-individual variability, each composite sample consisted of at least 50 mussels of similar size (45-55 mm shell length) collected from each sampling site. All samples were systematically depurated in filtered water for 24 hours before freezing, to allow a natural clearance of particles from the digestive tracts and mantle of the shellfish. The shellfish were shelled and their flesh (whole soft body) was homogenized and stored at $-20{ }^{\circ} \mathrm{C}$ prior to freeze-drying. The samples were stored in a dry, cool and dark place until further analysis.

In order to check potential increase in water content during storage, gravimetric determination of constant dry weight (dw) was systematically conducted on an aliquot of each sample before sample extraction. This precaution was particularly important for the analysis of archived samples, some of which had been stored for over 30 years. However, no increase in water content (on average about 8\%) was found in relation to sample storage duration.

\subsection{Chemicals}

Details on the solvents and standards used are provided in the Supplementary Material (SM).

\subsection{Sample preparation and analysis}

HBCD and PFC analyses were performed at the LABERCA laboratory as described below. Further details on all analytical procedures are provided in the SM.

For HBCD analysis, the samples were extracted by Accelerated Solvent Extraction (ASE) using toluene and acetone (70:30, v:v). The total amount of extractable lipids was determined gravimetrically on this extract before further sample processing. Purification was performed 
on a column comprising successive layers of anhydrous sodium sulfate, neutral silica gel, and concentrated sulphuric acid acidified silica. HBCD stereoisomers were analyzed using reverse-phase LC (Hypersil Gold column, $100 \mathrm{~mm} \times 2.1 \mathrm{~mm}, 1.9 \mu \mathrm{m}$ ), and determined by LC-MS/MS (Agilent 6410) fitted with an electrospray ion source, operating in the negative ion mode.

For PFC analysis, the samples were extracted by liquid solid extraction using methanol. The extracts were purified using dispersive solid phase extraction with Envicarb stationary phase, according to a method described by Powley et al. (2005) followed by a hydrated silica column. The purified extracts were separated using LC equipped with a $\mathrm{C}_{18}$ reverse phase column $(50 \mathrm{~mm} \times 2.0 \mathrm{~mm}, 3 \mu \mathrm{m})$ fitted with a guard column $(10 \mathrm{~mm} \times 2.0 \mathrm{~mm}, 3 \mu \mathrm{m})$ and interfaced with a linear ion trap coupled to an orbital trap (LTQ-OrbitrapTM) (Thermo Scientific, Germany) operating in negative electrospray ionization mode.

\section{4. $Q A / Q C$}

LABERCA laboratory operates an ISO/IEC 17025:2005-certified Quality Assurance system requiring strict controls as regards personnel, instrument conditions, and experimental situations. The three HBCD isomers and various PFCs were quantified by isotopic dilution using the corresponding ${ }^{13} \mathrm{C}$-labelled isomers, and real samples were quantified using internal standard method. Laboratory blanks were simultaneously analysed and monitored in parallel with the samples, and the signal of each compound in the blanks was checked to avoid contamination throughout the analytical procedure. A reference fish sample (for HBCD analysis) and egg sample (for PFC analysis) were included in each series of analysis to assure 
repeatability. The results obtained for the fish and egg samples were used to set up a quality control chart guaranteeing the robustness of the entire analytical procedure. In addition, our laboratory regularly takes part in inter-laboratory comparison tests and achieves good results for both of these methods. Moreover, our analytical methods have been approved and accredited by the French accreditation body, with an overall uncertainty of between $24 \%$ and $29 \%$ depending on the compound.

The LOQ value was determined for each target compound in each analysed sample. LOQ was between $0.0002 \mathrm{ng} \mathrm{g}^{-1}$ ww and $0.002 \mathrm{ng} \mathrm{g}^{-1}$ ww for each HBCD isomer, and between $0.02 \mathrm{ng}$ $\mathrm{g}^{-1} \mathrm{ww}$ and $0.2 \mathrm{ng} \mathrm{g} \mathrm{ww}^{-1}$ according to the PFC compound.

\section{Results and discussion}

\subsection{HBCD levels and patterns}

The geographical distribution of $\Sigma$-HBCD concentrations determined in shellfish is shown in Fig. 2 for samples collected along the French coast in 2008 and 2010. Although HBCDs are present in the technical mixture primarily in the form of three stereoisomers $(\alpha-, \beta$-and, predominantly, $\gamma$ - HBCD), $\alpha-\mathrm{HBCD}$ was shown to prevail in both mussels and oysters, accounting for an average of $90 \%$ of the sum of three isomers. $\beta$-HBCD concentrations were below the limit of detection in most of the samples. The prevalence of alpha-HBCD is usually observed in aquatic biota due to its higher assimilation efficiency and/or slower degradation (Haukås et al., 2009). A significant linear correlation $(\mathrm{r}=0.86, \mathrm{p}<0.05)$ was observed between $\gamma$ - and $\alpha$-isomer concentrations. No spatial trend was observed in HBCD patterns. 
$\alpha-\mathrm{HBCD}$ was detected in all samples, revealing the ubiquitous contamination of French coasts by this BFR. In 2008, $\Sigma$-HBCD concentrations varied from $0.03 \mathrm{ng} \mathrm{g}^{-1}$ wet weight (ww) at the Etel estuary to $0.55 \mathrm{ng} \mathrm{g}^{-1} \mathrm{ww}$ at the Nivelle estuary, both located on the Atlantic coast (Fig. 1). In 2010, minimum and maximum concentrations were found at the same sites, ranging from $0.01 \mathrm{ng} \mathrm{g}^{-1}$ ww to $0.36 \mathrm{ng} \mathrm{g}^{-1}$ ww. As shown in Fig. 2, concentrations were markedly lower in 2010 than in 2008 at all sites, on average by a factor of 0.7 . The highest concentrations in the English Channel were found at the Seine estuary site $\left(0.41 \mathrm{ng} \mathrm{g}^{-1} \mathrm{ww}\right.$ and $0.31 \mathrm{ng} \mathrm{g}^{-1} \mathrm{ww}$ in 2008 and 2010 respectively) and Antifer site ( $0.26 \mathrm{ng} \mathrm{g}^{-1} \mathrm{ww}$ and 0.20 $\mathrm{ng} \mathrm{g}^{-1} \mathrm{ww}$ in 2008 and 2010 respectively), the latter being under the influence of the Seine estuary. Higher levels of various POPs (namely, PCBs, PCDD/Fs, and PBDEs) have previously been reported related to high inputs from human activities via the Seine river (Johansson et al., 2006; Munschy et al., 2008). Concentrations in samples from the Mediterranean coast were generally in the high range too (0.07-0.41 $\mathrm{ng} \mathrm{g}^{-1} \mathrm{ww}$ in both 2008 and 2010) versus the Atlantic. Samples from the Atlantic coast showed lower contamination levels (0.01-0.06 $\mathrm{ng} \mathrm{g}^{-1} \mathrm{ww}$ ), except those originating from La Nivelle estuary in both 2008 and 2010, which were in a similar range to those found in samples from the Seine estuary. This sampling site was revisited in November 2011, leading to a confirmation $\left(0.45 \mathrm{ng} \mathrm{g}^{-1}\right.$ ww) of the high contamination level observed previously. This estuary also shows higher PBDE contamination on the Atlantic coast (unpublished results), although no evidence of major BFR local sources (i.e., industrial) could be found. Indeed, the Nivelle river is a small coastal stream, which drains a mountainous catchment area before reaching the Bay of Biscay (Atlantic Ocean). 
The spatial distribution of HBCD concentrations varied according to the sampling site. Median concentrations calculated in each coastal area decreased as follows: Mediterranean coast > English Channel > Atlantic coast (Table 1). Distribution appears to correspond to France's most highly-populated and/or industrialized areas. Human activities are obviously at the origin of the presence of these chemicals in the environment, although a previous study conducted in Japan showed that HBCD presence was related more to industrial activity than to highly populated areas (Ueno et al., 2010).

To our knowledge, data on HBCD contamination of the French coastal environment is nonexistent. In the marine environment, most available data on HBCD contamination relates to fish (Law et al., 2008b), related to HBCD biomagnification along trophic networks (Covaci et al., 2006; Tomy et al., 2008; Haukås et al., 2010). Even on a worldwide scale, data on shellfish contamination by HBCDs is limited versus PBDE data (Ueno et al., 2010). Table 1 presents available data on the contamination of shellfish by HBCDs in European countries. The data available in the literature is usually reported as $\Sigma$-HBCD expressed in $\mathrm{ng} \mathrm{g}^{-1} \mathrm{ww}$ or $\mathrm{ng} \mathrm{g}^{-1}$ lipid weight (lw). Although HBCD concentrations showed no significant correlation with lipid content in our samples (either in 2008 or in 2010), concentrations were also expressed normalised to lipid content for comparison purposes (Table 1). Data from the literature differs widely, i.e., from non-detected values to $329 \mathrm{ng} \mathrm{g}^{-1}$ ww depending on the characteristics of the sampling area (i.e. proximity to sources). Data comparison on a European scale shows levels determined in the French coastal environment to be in a similar range to those reported in other European countries (i.e., Netherlands, Norway, UK), with the exception of the much higher concentrations reported by Berge et al. (2006) on the West coast 
of Norway, i.e., 55.4-329 $\mathrm{ng} \mathrm{g}^{-1} \mathrm{ww}$, related to the production of polystyrene polymer products.

\subsection{PFC levels and patterns}

Among the various analysed PFCs, only PFOS was detected in all samples, indicating widespread contamination of the French coastal environment by this chemical. PFOS was found to be the predominant PFC in most samples collected from the English Channel and Atlantic coast, while PFCAs prevailed in Mediterranean samples. PFOS is reportedly the main PFC found in all species of aquatic biota throughout the world (Houde et al., 2011), although some studies have reported PFOA as being the predominant compound, for example in shellfish from Asia, related to direct sources (Nakata et al., 2006; Pan et al., 2010). The spatial distribution of PFOS concentrations is presented in Fig. 3: these were in the 0.005-0.87 $\mathrm{ng} \mathrm{g}^{-1} \mathrm{ww}$ range, with a median value of $0.08 \mathrm{ng} \mathrm{g}^{-1} \mathrm{ww}$. Median concentrations were higher in samples collected in the English Channel, followed by those from the Atlantic and Mediterranean coasts (Table 1). As previously seen for HBCDs, the Seine estuary area (Seine estuary and Antifer sites, Fig. 1) showed higher PFOS concentrations versus the other sites. This is consistent with the results obtained by Labadie and Chevreuil (2011) in the Seine river, where PFOS concentrations were found to be higher than in other European rivers. In our study, the highest concentration $\left(0.87 \mathrm{ng} \mathrm{g}^{-1} \mathrm{ww}\right)$ was found in one sample collected from the Loire estuary site on the Atlantic coast (Fig. 3). The site was revisited in November 2011, at which time the previously-observed high level of contamination was confirmed $\left(0.68 \mathrm{ng} \mathrm{g}^{-1}\right.$ ww). This result is unexpected, as the Loire estuary catchment area is not particularly 
industrialized or urbanized in comparison to the Seine river catchment area. As a result, the Loire estuary does not show high concentrations of classic organic contaminants such as PCBs or PCDD/Fs, or more recently-emerged compounds such as PBDEs (unpublished results) and HBCDs (this study). PFOS has been identified in effluents from the paper and metal industry and, in particular, at high concentrations in industrial effluents from galvanising, nickel and chromium plating and metal anodising (Clara et al., 2008; Xiao et al., 2012). The "Pays de la Loire" region, where the Loire estuary is located, is France's foremost region for the wood transformation and paper industry, and metal surface treatment industry, both of which represent potential sources of PFOS. The higher PFOS concentrations found in mussels at this site should therefore continue to be monitored in coming years.

Few studies report PFC presence in shellfish from the marine environment, and, to our knowledge, none is available to date for France. Available data on PFOS concentrations in shellfish is summarized in Table 1. PFOS was not detected or was found at low levels in shellfish from most other European coastal areas (Bossi et al., 2008; Nania et al., 2009; Fernández-Sanjuan et al., 2010; Gómez et al., 2011) with the exception of mussels from north-central Portuguese estuaries crossing the country's most industrialized areas, in which high concentrations were detected (Cunha et al., 2005). Our data reveals a ubiquitous and fairly high contamination of French coastal areas by PFOS versus other countries.

Although most data on biota reported in the literature concerns PFOS and PFOA, more recent studies show evidence of the occurrence of other PFCs, for example in Asia (So et al., 2006; Yoo et al., 2009; Naile et al., 2010; Pan et al., 2010;Wang et al., 2011) and Brazil (Quinete et al., 2009). In our study, the second most-frequently detected compound (38\% of samples, 
Table SM-1), perfluorodecanoic acid (PFDA), was determined at lower levels than PFOS, i.e. between 0.04 and $0.08 \mathrm{ng} \mathrm{g}^{-1} \mathrm{ww}$ (Table SM-1). PFDA occurrence in shellfish has barely been reported in the literature and, to our knowledge, never in Europe. PFDA has been identified at concentrations second to PFOS in sewage sludge from WWTPs in Denmark, but it has not been detected in mussels (Bossi et al., 2008). It was identified in various invertebrates from Korea at levels of between $<\mathrm{MDL}$ (method detection limit) and $2.08 \mathrm{ng} \mathrm{g}^{-1}$ dw (Naile et al., 2010), and in mussels and oysters from the East Chinese Coast and Tokyo Bay in Japan at $<0.11-0.13 \mathrm{ng} \mathrm{g}^{-1}$ ww and (So et al., 2006). Perfluoroundecanoic acid (PFUnA) was detected in Mediterranean samples only, at levels of between 0.32 and $0.59 \mathrm{ng}$ $\mathrm{g}^{-1} \mathrm{ww}$, i.e. slightly lower than the levels reported in mussels by Naile et al. (2010) (1.09-1.61 $\left.n g \mathrm{~g}^{-1} \mathrm{ww}\right)$. Perfluorododecanoic acid (PFDoA), perfluorotridecanoic acid (PFTrDA) and perfluorotetradecanoic acid (PFTeDA) were detected at the Gulf of Fos site alone, at $0.51 \mathrm{ng}$ $\mathrm{g}^{-1} \mathrm{ww}, 0.44 \mathrm{ng} \mathrm{g}^{-1} \mathrm{ww}$ and $0.11 \mathrm{ng} \mathrm{g}^{-1}$ ww respectively (Table SM-1). PFDoA levels were in the same range as those found in mussels from Korea and oysters from Tokyo Bay (Naile et al., 2010; So et al., 2006).

PFOSA (the main PFOS precursor) was detected in four samples (Antifer, Seine estuary, Loire estuary and Gulf of Fos) influenced by urban and/or industrial activities. Concentrations at three out of these four sites were higher than those of PFOS and found to be in the 0.36$1.79 \mathrm{ng} \mathrm{g}^{-1}$ ww range. No correlation between PFOS and PFOSA could be found: however, only a small amount of data was obtained. These levels are comparable to those reported by So et al. (2006) in mussels and oysters from the East China Coast and Tokyo Bay in Japan, where the high levels of this compound have been associated with the extensive use of 
insecticides to control termites and ants. In another study, PFOSA was not detected in industrial effluents and barely detected in municipal WWTPs (Clara et al., 2008). PFCs are used in a broad range of applications, such as surfactants, lubricants, paper and textile coatings, polishes, food packaging and fire-retarding foams (Calafat et al., 2006). The pattern observed in biota is the result of source exposure, assimilation and elimination, and cannot therefore be used alone to track sources. In our study, several of the compounds identified in shellfish, such as PFDA, PFDoA and PFOS, reportedly originate mainly from industrial sources (Clara et al., 2008). In the Mediterranean samples, PFCAs prevailed over PFOS (Fig. 4), with a PFCAs / PFOS ratio at the Gulf of Fos and Bay of Hérault of 11 and 14, respectively. Among PFCAs, those with odd carbon number were present in higher proportions versus the corresponding shorter even-chain length PFCAs (e.g., PFUnA > PFDA). The predominance of odd-chain length PFCAs has previously been observed in fish and partially explained by the degradation of fluorotelomer alcohols (FTOHs) (Ellis et al., 2004; Martin et al., 2004). In Denmark, PFCAs have been identified at high concentrations in effluent waters from the textile industry, but they may also originate from other industrial activities (Bossi et al., 2008). Interestingly, the two patterns determined at the Hérault bay and Gulf of Fos sites (Fig. 1) showed some dissimilarities: mainly shorter chain PFCAs (< PFDoA) were observed in the former, while longer chain PFCAs (> PFUnA) prevailed in the latter (Fig. 4). The Gulf of Fos is bordered by a heavily industrialized area, with chemical, petroleum and steel-work plants, and receives freshwater inputs from the river Rhone, three channels and the Berre Lagoon (Mille et al, 2007). The different patterns observed in Mediterranean samples versus samples from the other coastal areas may indicate a variety of 
sources. However, the reasons for the varying patterns we observed remains unclear and difficult to link to specific industrial activities. More data on industrial activities together with potential PFC sources would be needed in order to explain the patterns observed in shellfish.

\subsection{HBCD and PFC trends}

Both the temporal trends of $\mathrm{HBCD}$ and PFC concentrations were investigated at the Seine estuary site between 1981 and 2011 using archived samples from the French ESB held by Ifremer. This site is a French benchmark in terms of highly-contaminated estuaries.

Moreover, the data obtained in this study is complementary to the previous studies on POPs (PCBs, PCDD/Fs, PBDEs) conducted by us at this site (Johansson et al., 2006; Munschy et al., 2008).

The temporal trend of HBCD concentrations ( $\alpha$-isomer) in mussels from the Seine estuary between 1981 and 2011 is presented in Fig. 5, with concentrations in the 0.01-0.39 $\mathrm{ng} \mathrm{g}^{-1} \mathrm{ww}$ range. Although concentrations decreased between 2008 and 2010 at all geographical sites (see section 3.1), including the Seine estuary, the data obtained from the Seine estuary samples between 1981 and 2011 reveal a significant exponential upward trend over the entire study period, with a doubling time of 8 years. Similarly to our previous results on PCBs and PBDEs, a concentration higher than that predicted by the exponential curve was observed in the years 2000 and 2008, linked to higher flooding of the Seine River (Johansson et al., 2006; Munschy et al., 2008).

Time trend studies published in the literature show diverging results, ranging from increasing trends to insignificant or decreasing trends. Johansson et al. (2011) revealed a significant 
increase of $11 \%$ per year in HBCD concentrations in Peregrine falcon in Sweden from the mid-1980's until 2005, followed by an apparent levelling-off and decline after 2000. The same trend was previously observed by Sellström et al. (2003) in guillemot eggs between 1969 and 2000, with a two-fold increase in concentrations over the study period followed by levelling-off since the mid-1990s. An upward trend was detected in bird eggs from Northern Norway between 1983 and 2003 (Covaci et al., 2006). Vorkamp et al. (2011) found a statistically significant exponential time trend in ringed seals from East Greenland, with an annual increase of $6.1 \%$. Conversely, several recent studies have shown decreasing trends, generally related to a local drop in production or industrial emissions, for example in the UK and in Germany, with various time lags after production stoppage (Law et al., 2008a;

Esslinger et al., 2011). The results obtained in the Seine estuary did not suggest any recent reductions in point source emissions.

HBCD trends contrast with those generally observed in PBDEs (except BDE-209) in Europe, the levels of which have decreased or stabilised in recent years due to European regulations or even voluntary withdrawal (Law et al., 2010; Johansson et al., 2011). Indeed, PBDEs (pentaand octa-BDE products) have been banned since 2004 in Europe, while no regulations exist to date for HBCD. de Wit et al (2010) reported that the global use of HBCD has increased slightly since 2001, with 16,700 tons in 2001, 21,400 in 2002 and 22,000 tons in 2003. However, total HBCD volumes sold in Europe have been relatively stable, with 9,500 tons in 2001, 10,897 tons in 2007 and 8913 tons in 2008 (de Wit et al., 2010; VECAP, 2009). This obviously does not explain the increasing levels observed in the Seine estuary. The upward trend observed in our study may suggest that HBCD is increasingly used as alternative to 
PBDEs, as previously suggested by several authors (Lam et al., 2009; Wu et al., 2012).

However, additional studies may be required to monitor the evolution of concentrations at this site and investigate trends in France on a wider scale.

The temporal variations in PFOS concentrations at the Seine estuary site showed a significant linear decrease $(r=0.89, \alpha=0.05)$ between 1990 and 2011 (Fig. 6). Although the observed trend was significant over this time period, concentrations did not vary widely between 1990 and 2002 (1.42-2.58 $\mathrm{ng} \mathrm{g}^{-1} \mathrm{ww}$ range), and lower concentrations were observed in the 20042011 period (1.07-0.26 $\mathrm{ng} \mathrm{g}^{-1} \mathrm{ww}$ range). The observed trend appears to be consistent with other studies, which show an increase in PFOS levels in many industrialized countries until the mid-1990s, followed by a decline, which may or may not be significant (Kwadjik et al., 2010). More specifically, decreasing PFOS concentrations were found in Europe between 1999 and 2008 in harbour seals from the German Bight (Ahrens et al., 2009), although this decrease was not significant. In ringed seals from the Baltic Sea, PFOS concentrations showed a statistically significant increase between 1974 and 2008, although the trend levelled-off after 1997 and no significant trend was observed after this date (Kratzer et al., 2011). Eel samples from The Netherlands showed a PFOS increase from the end of the 1970s to the mid-1990s, followed by a significant decrease from the late 1970s until 2008 (Kwadjik et al., 2010). Galatius et al. (2011) reported no significant correlation in PFOS concentrations in harbour porpoises from the Danish North Sea between 1980 and 2005, while decreasing trends (although not significantly so) were found in harbour porpoises from Northern Europe between 1991 and 2008 (Huber et al., 2012). 
It therefore appears that the decline observed in the environment occurred before PFOS manufacture was phased out by the company 3M between 2000 and 2002, although minor PFOS production continued in Europe $(<42-82 \mathrm{t}$ in 2003) for restricted applications (Ahrens et al., 2009; Paul et al., 2009; Houde et al., 2011). In contrast, increasing PFCA concentrations were reported, for example in harbour porpoises from Northern Europe, suggesting continuous inputs of these compounds into the marine environment (Huber et al., 2012).

\section{Conclusions}

Our study showed evidence of widespread contamination of the French coastal environment by HBCDs and PFCs, and in particular PFOS, which is the most prevalent PFC. HBCD levels were in the ranges reported in other European countries, while PFOS levels were comparatively high, although very little data is available to date. Other PFCs, in particular long-chain PFCAs, were also identified at some sites, especially in Mediterranean samples where they were predominant, suggesting the existence of a variety of sources.

A significant exponential increase in HBCD levels was observed in the Seine estuary between 1981 and 2011, suggesting a regular input of this compound into the marine environment. PFOS temporal trends showed opposite results, with a significant linear decrease since 1990. These trends coincide with the global trends observed in Europe and with regulations on the emission and use of these compounds.

The data obtained in this study is the first reported on a national scale. Further studies are now required to assess French coastal contamination by emerging compounds and their temporal 
trends. The French ESB is of major interest for this purpose.

\section{Acknowledgements}

The authors would like to thank the ONEMA (Office National de l'Eau et des Milieux Aquatiques) for its financial backing. Didier Claisse and the IFREMER staff are gratefully acknowledged for coordinating the French Mussel Watch network and performing the sampling campaigns, respectively. We acknowledge Laura Valentine from "English Assistance for Industry” for the English corrections made to the manuscript. 


\section{References}

Ahrens, L., Siebert, U., Ebinghaus, R., 2009. Temporal trends of polyfluoroalkyl compounds in harbor seals (Phoca vitulina) from the German Bight, 1999-2008. Chemosphere 76, 151-158.

Ahrens, L., 2011. Polyfluoroalkyl compounds in the aquatic environment: a review of their occurrence and fate. J. Environ. Monit. 13, 20-31.

Becker, P.R., Wise, S.A., 2010. Thirty years of progress in environmental specimen banking. In: Isobe, T., Nomiyama, K., Subramanian, A., Tanabe, S. (Eds.). Environmental Specimen Bank. Exploring possibility of setting-up ESBs in developing countries. Proceedings of the international symposium on environmental specimen banks held at Ehime University, Japan, 3-5 December, 2009, pp. 7-14.

Beliaeff, B., O'Connor, T.P., Munschy, C., Raffin, B., Claisse, D., 2002. Comparison of polycyclic aromatic hydrocarbon levels in mussels and oysters in France and the United States. Environ. Toxicol. Chem. 21, 1783-1787.

Berge, J.A., Schlabach, M., Fjeld, E., 2006. BFR contamination of the marine environment around the city of Ålesund, Norway. Organohalogen Compd 68, 53-56.

Bossi, R., Strand, J., Sortkjær, O., Larsen, M.M., 2008. Perfluoroalkyl compounds in Danish wastewater treatment plants and aquatic environments. Environ. Int. 34, 443-450.

Calafat, A.M., Kuklenyik, Z., Caudill, S.P., Reidy, J.A., Needham, L.L., 2006. Perfluorochemicals in pooled serum samples from United States residents in 2001 and 2002. Environ. Sci. Technol. 40, 2128-2134. 
Clara, M., Scheffknecht, C., Scharf, S., Weiss, S., Gans, O., 2008. Emissions of perfluorinated alkylated substances (PFAS) from point sources - identification of relevant branches. Water Sci. Technol. 58, 59-66.

Clarke, D.B., Bailey, V.A., Routledge, A., Lloyd, A.S., Hird, S., Mortimer, D.N., Gem, M., 2010. Dietary intake estimate for perfluorooctanesulphonic acid (PFOS) and other perfluorocompounds (PFCs) in UK retail foods following determination using standard addition LC-MS/MS. Food Addit. Contam. 27, 530-545.

Covaci, A, Gerecke, A.C., Law, R.J., Voorspoels, S., Kohler, M., Heeb, N.V., Leslie, H., Allchin, C.R., de Boer, J., 2006. Hexabromocyclododecanes (HBCDs) in the environment and humans: a review. Environ. Sci. Technol. 40, 3679-3688.

Cunha, I., Hoff, P., Van de Vijver, K., Guilhermino, L., Esmans, E., De Coen, W., 2005. Baseline study of perfluorooctane sulfonate occurrence in mussels, Mytilus galloprovincialis, from north-central portuguese estuaries. Mar. Pollut. Bull. 50, 11211145.

de Wit, C.A., Herzke, D., Vorkamp, K., 2010. Brominated flame retardants in the Arctic environment - trends and new candidates. Sci. Total Environ. 408, 2885-2918.

Ellis, D.A., Martin, J.W., De Silva, A.O., Mabury, S.A., Hurley, M.D., Andersen, M.P.S., Wallington, T.J., 2004. Degradation of fluorotelomer alcohols: A likely atmospheric source of perfluorinated carboxylic acids. Environ. Sci. Technol. 38, 3316-3321.

Esslinger, S., Becker, R., Jung, C., Schröter-Kermani, C., Bremser, W., Nehls, I., 2011. Temporal trend (1988-2008) of hexabromocyclododecane enantiomers in herring gull eggs from the German coastal region. Chemosphere 83, 161-167. 
Falandysz, J., Taniyasu, S., Gulkowska, A., Yamashita, N., Schulte-Oehlmann, U., 2006. Is fish a major source of fluorinated surfactants and repellents in humans living on the Baltic coast? Environ. Sci. Technol. 40, 748-751.

Fernandes, A., Dicks, P., Mortimer, D., Gem, M., Smith, F., Ield, M.D., White, S., Rose, M., 2008. Brominated and chlorinated dioxins, PCBs and brominated flame retardants in Scottish shellfish: Methodology, occurrence and human dietary exposure. Mol. Nutr. Food Res. 52, 238-249.

Fernández-Sanjuan, M., Meyer, J., Damásio, J., Faria, M., Barata, C., Lacorte, S., 2010. Screening of perfluorinated chemicals (PFCs) in various aquatic organisms. Anal. Bioanal. Chem. 398, 1447-1456.

Galatius, A., Dietz, R., Rigét, F.F., Sonne, C., Kinze, C.C., Lockyer, C., Bossi, R., 2011. Temporal and life history related trends of perfluorochemicals in harbor porpoises from the Danish North Sea. Mar. Pollut. Bull. 62, 1476-1483.

Giesy, J.P., Kannan, K., 2001. Global distribution of perfluorooctane sulfonate in wildlife. Environ. Sci. Technol. 35, 1339-1342.

Gómez, C, Vicente, J., Echavarri-Erasun, B., Porte, C., Lacorte, S., 2011. Occurrence of perfluorinated compounds in water, sediment and mussels from the Cantabrian Sea (North Spain). Mar. Pollut. Bull. 62, 948-955.

Goscinny, S., Vandevijvere, S., Maleki, M., Van Overmeire, I., Windal, I., Hanot, V., Blaude, M-N., Vleminckx, C., Van Loco, J., 2011. Dietary intake of hexabromocyclododecane diastereoisomers $(\alpha-, \beta-$, and $\gamma$-HBCD) in the Belgian adult population. Chemosphere 84 , 279-288. 
Haug, L.S., Thomsen, C., Brantsæter, A.L., Kvalem, H.E., Haugen, M., Becher, G., Alexander, J., Meltzer, H.M., Knutsen, H.K., 2010. Diet and particularly seafood are major sources of perfluorinated compounds in humans. Environ. Int. 36, 772-778.

Haukås, M., Hylland, K., Berge, J.A., Nygård, T., Mariussen, E., 2009. Spatial diastereomer patterns of hexabromocyclododecane (HBCD) in a Norwegian fjord. Sci. Total Environ. 407, 5907-5913.

Haukås, M., Hylland, K., Nygård, T., Berge, J.A., Mariussen, E., 2010. Diastereomer-specific bioaccumulation of hexabromocyclododecane (HBCD) in a coastal food web, Western Norway. Sci. Total Environ. 408, 5910-5916.

Houde, M., De Silva, A.O., Muir, D.C.G., Letcher, R.J., 2011. Monitoring of perfluorinated compounds in aquatic biota: an updated review. PFCs in aquatic biota. Environ. Sci. Technol. 45, 7962-7973.

Huber, S., Ahrens L., Bårdsen B-J, Siebert U., Bustnes J.O., Víkingsson G.A., Ebinghaus R., Herzke D., 2012. Temporal trends and spatial differences of perfluoroalkylated substances in livers of harbor porpoise (Phocoena phocoena) populations from Northern Europe, 1991-2008. Sci. Total Environ. 419, 216-224.

Johansson, I., Moisan, K., Guiot, N., Truquet, I., Munschy, C., Tronczyński, J., 2006. Polybrominated diphenyl ethers (PBDEs) in mussels from selected French coastal sites: 1981-2003. Chemosphere 64, 296-305.

Johansson, A.-K., Sellström, U., Lindberg, P., Bignert, A., de Wit, C.A., 2011. Temporal trends of polybrominated diphenyl ethers and hexabromocyclododecane in Swedish Peregrine Falcon (Falco peregrinus peregrinus) eggs. Environ. Int. 37, 678-686. 
Kratzer, J., Ahrens, L., Roos, A., Bäcklin, B.-M., Ebinghaus, R., 2011. Temporal trends of polyfluoroalkyl compounds (PFCs) in liver tissue of grey seals (Halichoerus grypus) from the Baltic Sea, 1974-2008. Chemosphere 84, 1592-1600.

Kwadijk, C.J.A.F., Korytár, P., Koelmans, A.A., 2010. Distribution of perfluorinated compounds in aquatic systems in the Netherlands. Environ. Sci. Technol. 44, 3746-3751.

Labadie, P., Chevreuil, M., 2011. Partitioning behaviour of perfluorinated alkyl contaminants between water, sediment and fish in the Orge River (nearby Paris, France). Environ. Pollut. 159, 391-397.

Lam, J.C.W., Lau, R.K.F., Murphy, M.B., Lam, P.K.S., 2009. Temporal trends of hexabromocyclododecanes (HBCDs) and polybrominated diphenyl ethers (PBDEs) and detection of two novel flame retardants in marine mammals from Hong Kong, South China. Environ. Sci. Technol. 43, 6944-6949.

Law, R.J., Kohler, M., Heeb, N.V., Gerecke, A.C., Schmid, P., Voorspoels, S., Covaci, A., Becher, G., Janák, K., Thomsen, C., 2005. Hexabromocyclododecane challenges scientists and regulators. Environ. Sci. Technol. 39, 281a-287a.

Law, R.J., Bersuder, P., Barry, J., Wilford, B.H., Allchin, C.R., Jepson, P.D., 2008a. A significant downturn in levels of hexabromocyclododecane in the blubber of harbor porpoises (Phocoena phocoena) stranded or bycaught in the UK: an update to 2006. Environ. Sci. Technol. 42, 9104-9109.

Law, R.J., Herzke, D., Harrad, S., Morris, S., Bersuder, P., Allchin, C.R., 2008b. Levels and trends of $\mathrm{HBCD}$ and BDEs in the European and Asian environments, with some information for other BFRs. Chemosphere 73, 223-241. 
Law, R.J., Barry, J., Bersuder, P., Barber J.L., Deaville, R., Reid, R.J., Jepson, P.D., 2010. Levels and trends of brominated diphenyl ethers in blubber of harbor porpoises (Phocoena phocoena) from the U.K., 1992-2008. Environ. Sci. Technol. 44, 4447-4451.

Martin, J.W., Mabury, S.A., Solomon, K.R., Muir, D.C.G., 2003. Dietary accumulation of perfluorinated acids in juvenile rainbow trout (Oncorhynchus mykiss). Environ. Toxicol. Chem. 22, 189-195.

Martin, J. W., Smithwick, M.M., Braune, B.M., Hoekstra, P.F., Muir, D.C.G., Mabury, S.A., 2004. Identification of long-chain perfluorinated acids in biota from the Canadian Arctic. Environ. Sci. Technol. 38, 373-380.

Marvin, C.H., Tomy, G.T., Armitage, J.M., Arnot, J.A., McCarty, L., Covaci, A., Palace, V., 2011. Hexabromocyclododecane: current understanding of chemistry, environmental fate and toxicology and implications for global management. Environ. Sci. Technol. 45, 86138623.

Mille, G., Asia, L., Guiliano, M., Malleret, L., Doumenq, P., 2007. Hydrocarbons in coastal sediments from the Mediterranean sea (Gulf of Fos area, France). Mar. Pollut. Bull. 54, 566-575.

Munschy, C., Guiot, N., Heas-Moisan, K., Tixier, C., Tronczyński, J. 2008. Polychlorinated dibenzo-p-dioxins and dibenzofurans (PCDD/Fs) in marine mussels from French coasts: Levels, patterns and temporal trends from 1981 to 2005. Chemosphere 73, 945-953.

Naile, J.E., Khim, J.S., Wang, T.Y., Chen, C.L., Luo, W., Kwon, B.O., Park, J., Koh, C.H., Jones, P.D., Lu, Y.L., Giesy, J.P., 2010. Perfluorinated compounds in water, sediment, soil and biota from estuarine and coastal areas of Korea. Environ. Pollut. 158, 1237-1244. 
Nakata, H., Kannan, K., Nasu, T., Cho, H.S., Sinclair, E., Takemura, A., 2006. Perfluorinated contaminants in sediments and aquatic organisms collected from shallow water and tidal flat areas of the Ariake Sea, Japan: Environmental fate of perfluorooctane sulfonate in aquatic ecosystems. Environ. Sci. Technol. 40, 4916-4921.

Nania, V., Pellegrini, G.E., Fabrizi, L., Sesta, G., De Sanctis, P., Lucchetti, D., Di Pasquale, M., Coni, E., 2009. Monitoring of perfluorinated compounds in edible fish from the Mediterranean Sea. Food Chem. 115, 951-957.

O’Connor, T.P., Lauenstein, G.G., 2006. Trends in chemical concentrations in mussels and oysters collected along the US coast: update to 2003. Mar. Environ. Res. 62, 261-285.

OSPAR, 2009. JAMP guidelines for monitoring contamination in biota. OSPAR Commission monitoring guidelines. Ref. No 1999-2, 98 p. (2009 update).

Pan, Y., Shi, Y., Wang, Y., Cai, Y., Jiang, G., 2010. Investigation of perfluorinated compounds (PFCs) in mollusks from coastal waters in the Bohai Sea of China. J. Environ. Monit. 12, 508-513.

Paul, A.G., Jones, K.C., Sweetman, A.J., 2009. A first global production, emission, and environmental inventory for perfluorooctane sulfonate. Environ. Sci. Technol. 43, 386392.

Powley, C.R., George, S.W., Ryan, T.W., Buck, R.C., 2005. Matrix effect-free analytical methods for determination of perfluorinated carboxylic acids in environmental matrixes. Anal. Chem. 77, 6353-6358.

Prevedouros, K., Cousins, I.T., Buck, R.C., Korzeniowski, S.H., 2006. Sources, fate and transport of perfluorocarboxylates. Environ. Sci. Technol. 40, 32-44. 
Quinete, N., Wu, Q., Zhang, T., Yun, S.H., Moreira, I., Kannan, K., 2009. Specific profiles of perfluorinated compounds in surface and drinking waters and accumulation in mussels, fish, and dolphins from southeastern Brazil. Chemosphere 77, 863-869.

Ramu, K., Kajiwara, N., Sudaryanto, A., Isobe, T., Takahashi, S., Subramanian, A., Ueno, D., Zheng, G.J., Lam, P.K.S., Takada, H., Zakaria, M.P., Viet, P.H., Prudente, M., Tana, T.S., Tanabe, S., 2007. Asian mussel watch program: contamination status of polybrominated diphenyl ethers and organochlorines in coastal waters of Asian countries. Environ. Sci. Technol. 41, 4580-4586.

Ramu, K., Isobe, T., Takahashi, S., Kim, E.Y., Min, B.Y., We, S.U., Tanabe, S., 2010. Spatial distribution of polybrominated diphenyl ethers and hexabromocyclododecanes in sediments from coastal waters of Korea. Chemosphere 79, 713-719.

Reiner, J.L., O’Connell, S.G., Moors, A.J., Kucklick, J.R., Becker, P.R., Keller, J.M., 2011. Spatial and temporal trends of perfluorinated compounds in beluga whales (Delphinapterus leucas) from Alaska. Environ. Sci. Technol. 45, 8129-8136.

Sánchez-Avila, J., Meyer, J., Lacorte, S., 2010. Spatial distribution and sources of perfluorochemicals in the NW Mediterranean coastal waters (Catalonia, Spain). Environ. Pollut. 158, 2833-2840.

Sellström, U., Bignert, A., Kierkegaard, A., Häggberg, L., de Wit, C.A., Olsson, M., Jansson, B., 2003. Temporal trend studies on tetra- and pentabrominated diphenyl ethers and hexabromocyclododecane in guillemot egg from the Baltic Sea. Environ. Sci. Technol. 37, 5496-5501. 
612

613

Shaw, S.D., Berger, M.L., Weijs, L., Covaci, A., 2012. Tissue-specific accumulation of polybrominated diphenyl ethers (PBDEs) including Deca-BDE and hexabromocyclododecanes (HBCDs) in harbor seals from the northwest Atlantic. Environ. Int. doi:10.1016/j.envint.2012.01.001.

So, M. K., Taniyasu, S., Lam, P.K.S., Zheng, G.J., Giesy, J.P.,Yamashita, N., 2006. Alkaline digestion and solid phase extraction method for perfluorinated compounds in mussels and oysters from South China and Japan. Arch. Environ. Contam. Toxicol. 50, 240-248.

Tanabe, S., 2008. Temporal trends of brominated flame retardants in coastal waters of Japan and South China: retrospective monitoring study using archived samples from es-Bank, Ehime University, Japan. Mar. Pollut. Bull. 57, 267-274.

Tanabe, S., Ramu, K., 2012. Monitoring temporal and spatial trends of legacy and emerging contaminants in marine environment: results from the environmental specimen bank (esBANK) of Ehime University, Japan. Mar. Pollut. Bull. http://dx.doi.org/10.1016/j.marpolbul.2012.05.013.

Tomy, G.T., Pleskach, K., Oswald, T., Halldorson, T., Helm, P.A., Macinnis, G., Marvin, C.H., 2008. Enantioselective bioaccumulation of hexabromocyclododecane and congenerspecific accumulation of brominated diphenyl ethers in an eastern Canadian Arctic marine food web. Environ. Sci. Technol. 42, 3634-3639.

Ueno, D., Isobe, T., Ramu, K., Tanabe, S., Alaee, M., Marvin, C., Inoue, K., Someya, T., Miyajima, T., Kodama, H., Nakata, H., 2010. Spatial distribution of hexabromocyclododecanes (HBCDs), polybrominated diphenyl ethers (PBDEs) and organochlorines in bivalves from Japanese coastal waters. Chemosphere 78, 1213-1219. 
UNEP, 2009. Stockholm convention on persistent organic pollutants, CH/Default.aspx.

van Leeuwen, S.P.J., de Boer, J., 2008. Brominated flame retardants in fish and shellfish levels and contribution of fish consumption to dietary exposure of Dutch citizens to HBCD. Mol. Nutr. Food Res. 52, 194-203.

VECAP, 2009. The voluntary emission control action programme - Annual progress report, 2009. http://www.vecap.info/uploads/VECAP_report_22\%2001.pdf.

Vorkamp, K., Rigét, F.F., Bossi, R., Dietz, R., 2011. Temporal trends of hexabromocyclododecane, polybrominated diphenyl ethers and polychlorinated biphenyls in ringed seals from East Greenland. Environ. Sci. Technol. 45, 1243-1249.

Wang, T., Lu, Y., Chen C., Naile, J.E., Khim, J.S., Park, J., Luo, W., Jiao, W., Hu, W., Giesy, J.P., 2011. Perfluorinated compounds in estuarine and coastal areas of north Bohai Sea, China. Mar. Pollut. Bull. 62, 1905-1914.

Wang, Z., Scheringer, M., MacLeod, M., Bogdal C., Müller, C.E., Gerecke, A.C., Hungerbühler, K., 2012. Atmospheric fate of poly- and perfluorinated alkyl substances (PFASs): II. Emission source strength in summer in Zurich, Switzerland. Environ. Pollut. doi:10.1016/j.envpol.2012.03.037.

Wu, J., Zhang, Y., Luo, X., She, Y., Yu, L., Chen, S., Mai, B., 2012. A review of polybrominated diphenyl ethers and alternative brominated flame retardants in wildlife from China: Levels, trends, and bioaccumulation characteristics. J. Environ. Sci. 24, 183194. 
656 Xiao, F., Halbach, T.R., Simcik, M.F., Gulliver, J.S., 2012. Input characterization of 657 perfluoroalkyl substances in wastewater treatment plants: Source discrimination by 658 exploratory data analysis. Water Res. 46, 3101-3109.

659 Yoo, H., Yamashita, N., Taniyasu, S., Lee, K.T., Jones, P.D., Newsted, J.L., Khim, J.S., 660 Giesy, J.P., 2009. Perfluoroalkyl acids in marine organisms from Lake Shihwa, Korea. 661 Arch. Environ. Contam. Toxicol. 57, 552-560. 


\section{Figure captions}

2 Fig. 1: Sampling sites for study shellfish collected in 2008 and 2010 from the English

3 Channel, Atlantic coast and Mediterranean Sea

4

5 Fig. 2: $\Sigma$-HBCD concentrations ( $\left.\mathrm{ng} \mathrm{g}^{-1} \mathrm{ww}\right)$ in shellfish collected in 2008 and 2010 along

6 French coasts. nda $=$ no data available

7

8 Fig. 3: PFOS concentrations (ng g ${ }^{-1}$ ww) in shellfish collected in 2010 along French coasts.

9 nda= no data available

10

11 Fig. 4: PFC concentrations ( $\mathrm{ng} \mathrm{g}^{-1} \mathrm{ww}$ ) in shellfish collected from the Seine estuary, Loire

12 estuary and Mediterranean coast (Hérault Bay and Gulf of Fos) in 2010

13

14 Fig. 5: Temporal trends of HBCD concentrations ( $\alpha$-isomer, $\mathrm{ng} \mathrm{g}^{-1}$ ww) in mussel samples

15 (Mytilus edulis) from the English Channel (Seine estuary) between 1981 and 2011

16

17 Fig. 6: Temporal trends of PFOS concentrations ( $\mathrm{ng}^{-1} \mathrm{ww}$ ) in mussel samples (Mytilus

18 edulis) from the English Channel (Seine estuary) between 1981 and 2011

19 
Fig. 1

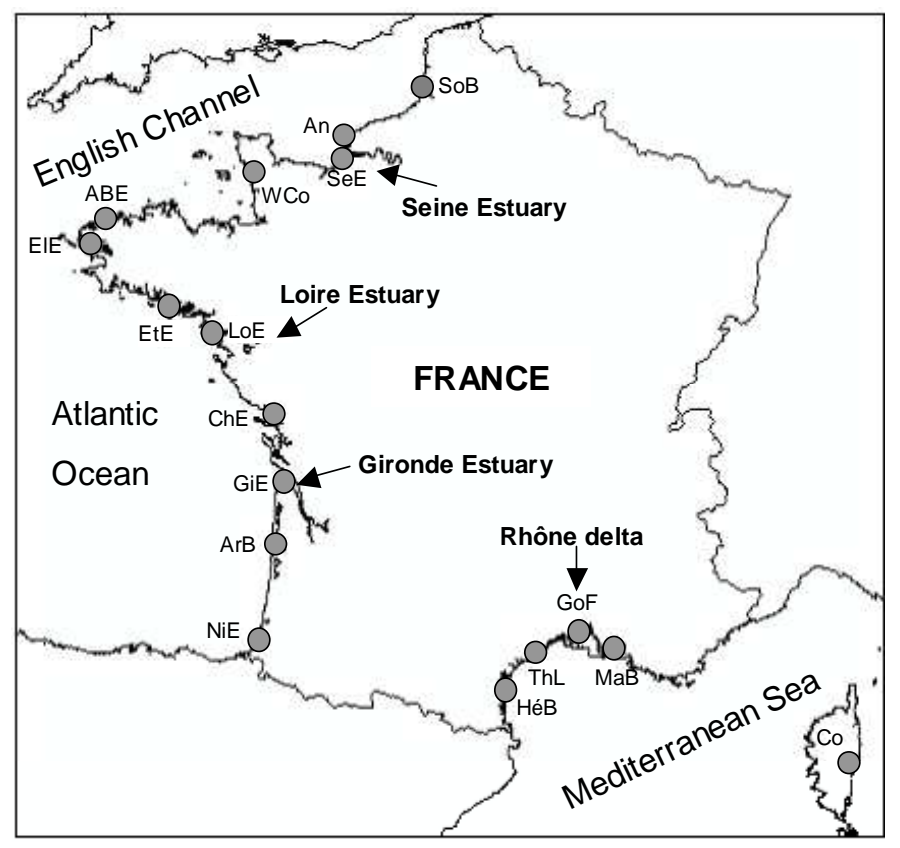

ENGLISH CHANNEL

SoB: Somme Bay

An: Antifer

SeE: Seine Estuary

WCo: West Cotentin

ABE: Aber Benoit Estuary

\section{ATLANTIC}

EIE: Elorn Estuary

EtE: Etel Estuary

LoE: Loire Estuary

ChE: Charente Estuary

GiE: Gironde Estuary

ArB: Arcachon Bay

NiE: Nivelle Estuary

\section{MEDITERRANEAN}

HéB: Hérault Bay

ThL: Thau Lagoon

GoF: Gulf of Fos

MaB: Marseille Bay

Co:Corsica 
Fig. 2

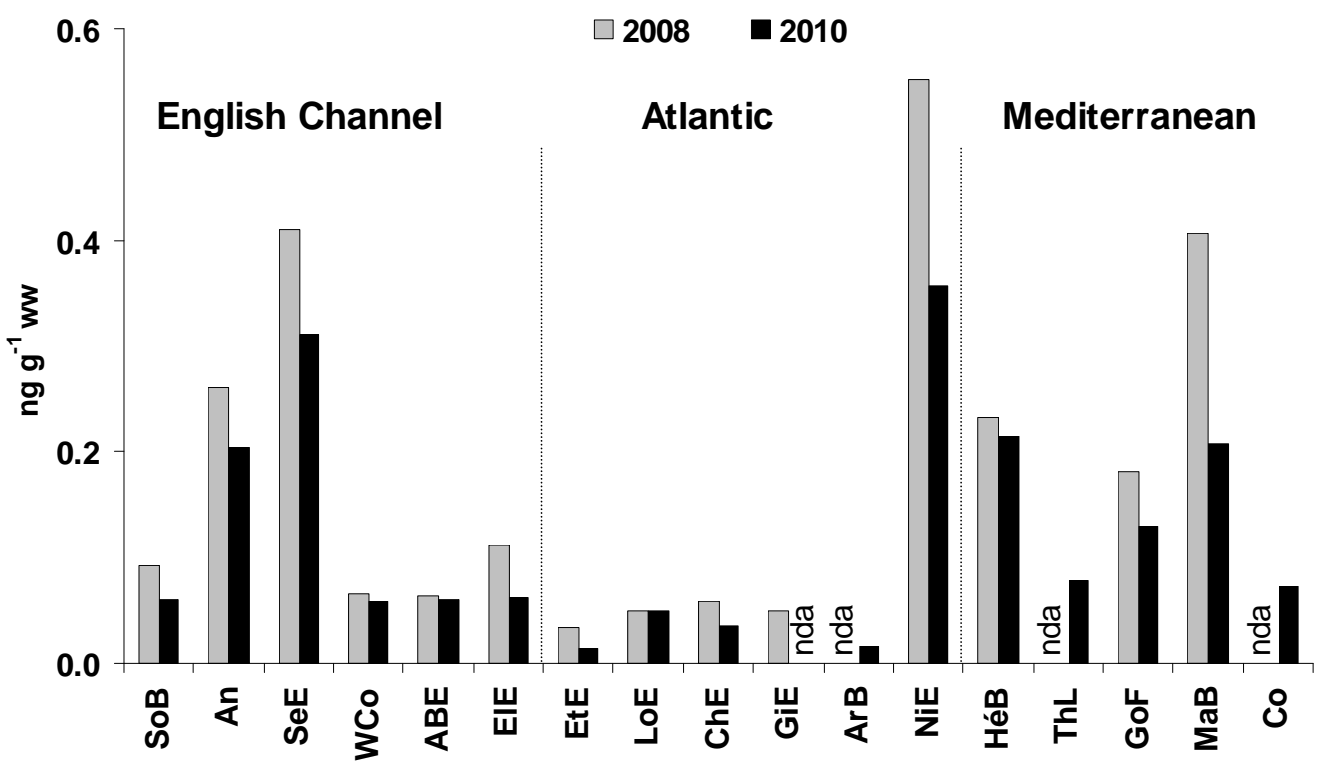


Fig. 3

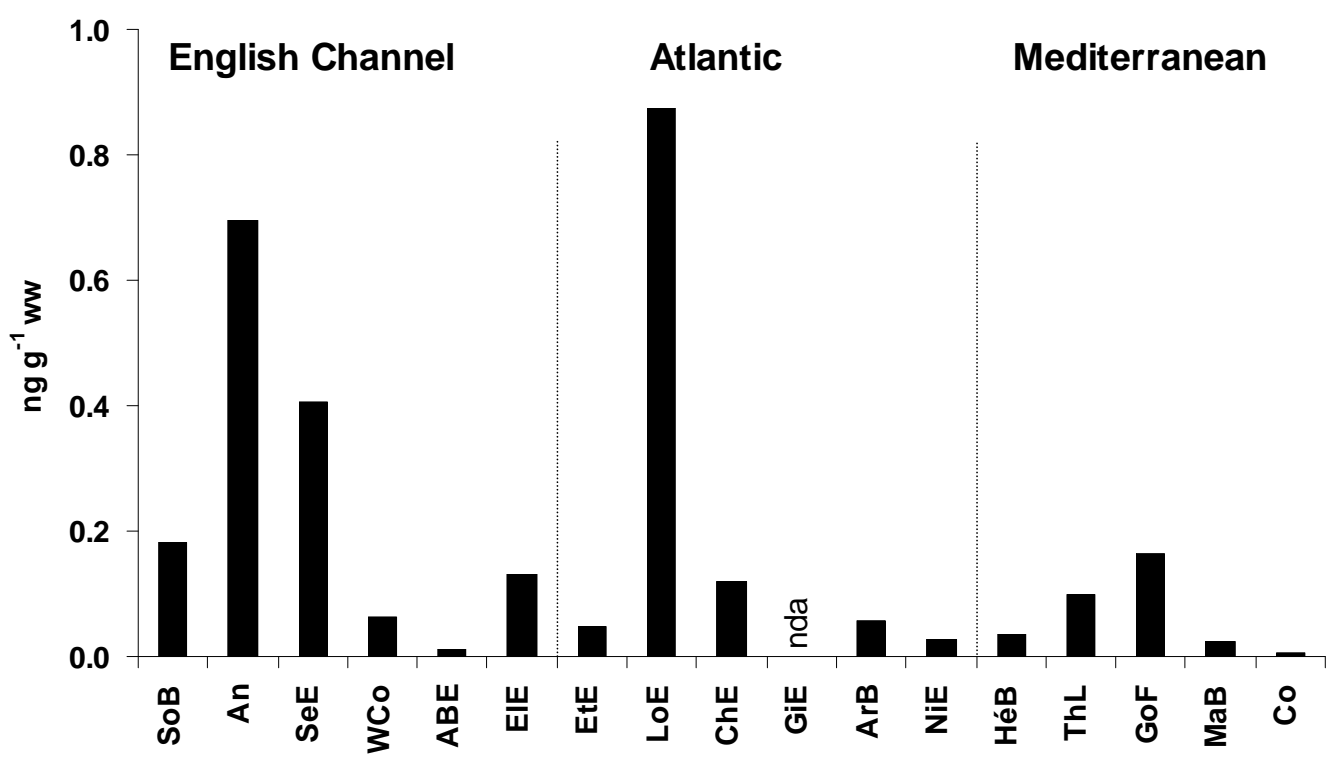


Fig. 4

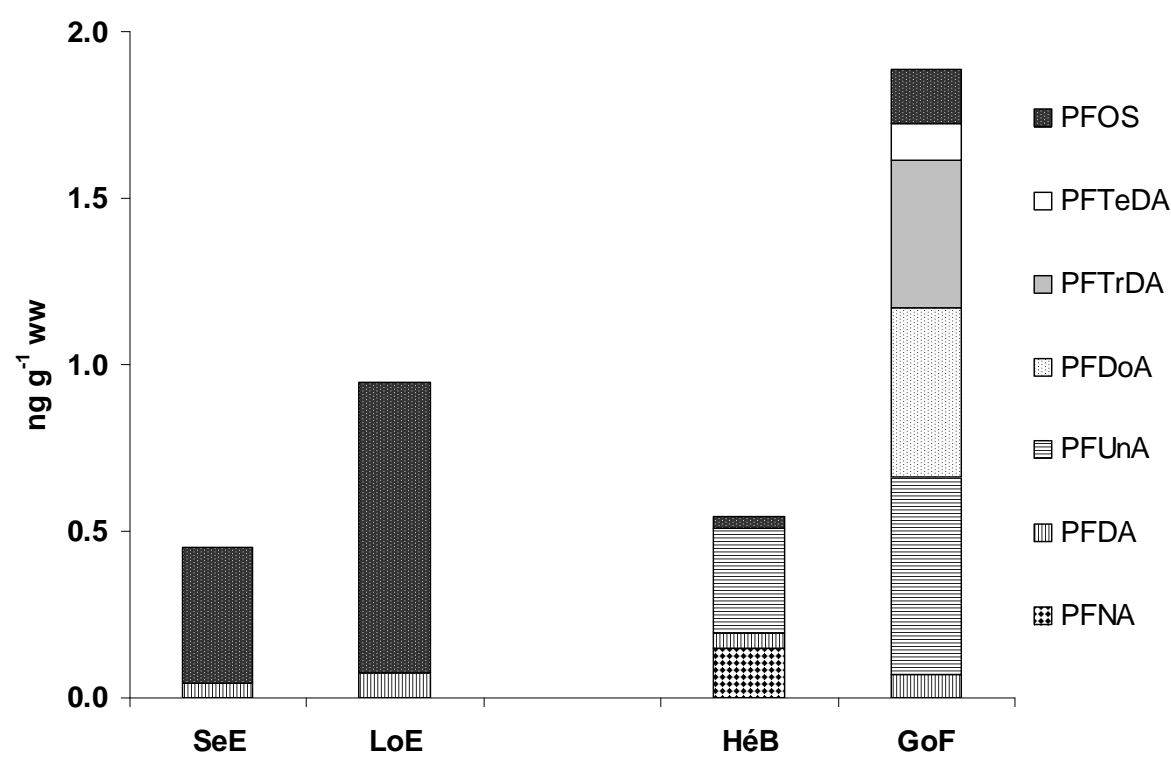


Fig. 5

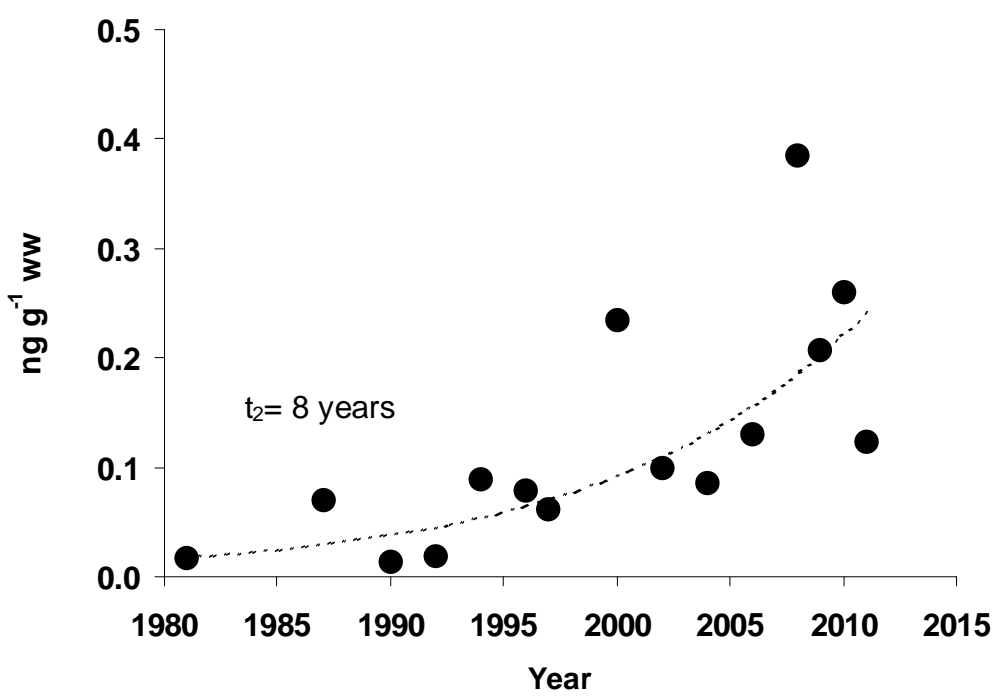


Fig. 6

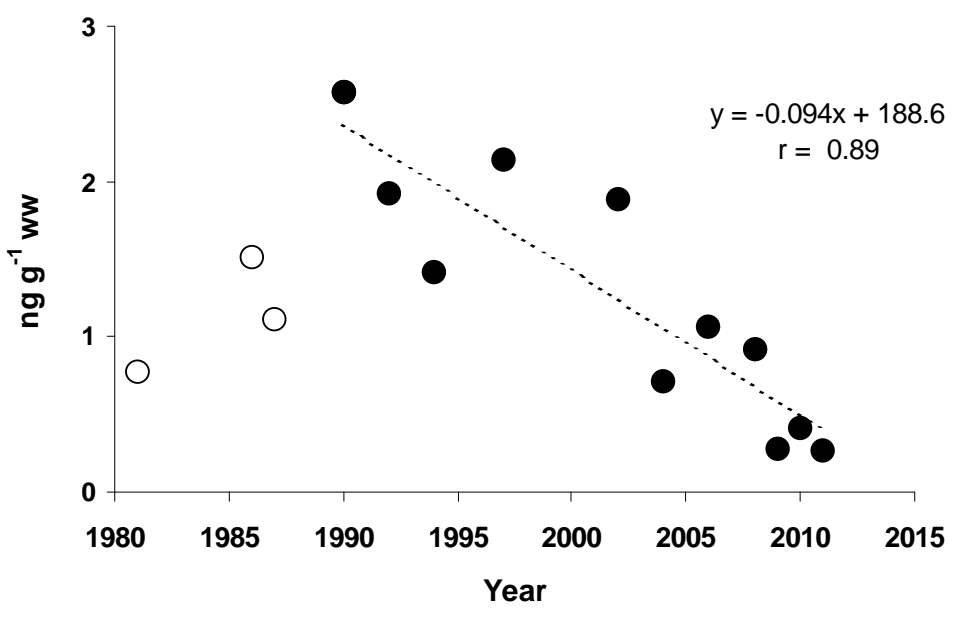


Table 1.

$\Sigma-H B C D$ and PFOS concentration ranges (minimum-maximum/median or mean) in shellifish from various coastal locations in Europe (including this study). Results are expressed in $\mathrm{ng}^{-1}$ wwunless otherwise stated.

\begin{tabular}{|c|c|c|c|c|}
\hline Location & $\begin{array}{l}\text { Sampling } \\
\text { period }\end{array}$ & $\begin{array}{l}\text { Concentrations } \\
\text { min-max/median or mean }\end{array}$ & Organism & Reference \\
\hline \multicolumn{5}{|l|}{$\Sigma-H B C D$} \\
\hline France (English Channel) & $2008-2010$ & $0.06-0.4110 .08$ & Mussels'oysters & This study \\
\hline France (Atlantic coast) & $2008-2010$ & $0.01-0.550 .04$ & Mussels'oysters & This study \\
\hline $\begin{array}{l}\text { France (Mediterranean } \\
\text { coast) }\end{array}$ & $2008-2010$ & $0.07-0.4110 .18$ & Mussels & This study \\
\hline France (all coasts) & $2008-2010$ & $0.67-30.7 / 3.4^{\mathrm{a}}$ & Mussels/oysters & This study \\
\hline Norway & 2001 & $10-106 / 34^{a}$ & Mussels & Covaci et al. (2006) \\
\hline $\begin{array}{l}\text { Norway (North West } \\
\text { coast) }\end{array}$ & 2006-2007 & $n d^{b}-109 / 48^{a}$ & Mussels & Haukás et al. (2010) \\
\hline Norway (South coast) & 2003-2004 & $<0.17-0.87 / 0.43$ & Mussels & Bethune et al. (2005) \\
\hline Norway (West coast) & 2004-2005 & $55.4-329$ & Mussels & Berge et al. (2006) \\
\hline $\begin{array}{l}\text { Netherlands } \\
\text { (Scheldt/Wadden Sea) }\end{array}$ & 2003 & $<0.1-0.9$ & Mussels & $\begin{array}{l}\text { van Leeuwen and de } \\
\text { Boer (2008) }\end{array}$ \\
\hline UK (Scotland) & 2006 & $0.192-12.1 / 0.56^{c}$ & Mussels/Oysters & $\begin{array}{l}\text { Fernandes et al. } \\
(2008)\end{array}$ \\
\hline \multicolumn{5}{|l|}{ PFOS } \\
\hline France (English Channel) & 2010 & $0.01-0.710 .2$ & Mussels'Oysters & This study \\
\hline France (Atlantic coast) & 2010 & $0.03-0.910 .1$ & Mussels oysters & This study \\
\hline $\begin{array}{l}\text { France (Mediterranean } \\
\text { coast) }\end{array}$ & 2010 & $0.005-0.210 .04$ & Mussels & This study \\
\hline UK & 2006 & $1-10 / 2.5$ & Oysters & Clarke et al. (2010) \\
\hline Denmark & - & $n d^{b}$ & Mussels & Bossi et al. (2008) \\
\hline Spain (North) & 2009 & $n d^{b}-0.06$ & Mussels (caged) & Gómez et al. (2011) \\
\hline Spain (North) & $2006-2009$ & $n d^{b}$ & Oysters (caged) & $\begin{array}{l}\text { Fernández-Sanjuan et } \\
\text { al. (2010) }\end{array}$ \\
\hline Portugal (North estuaries) & - & $36.8-125.9 / 72.0^{d}$ & Mussels & Cunha et al. (2005) \\
\hline Mediterranean Sea & - & $<2-3 /<2$ & Mussels/Clams & Nania et al. (2009) \\
\hline \multicolumn{5}{|l|}{ a Values expressed inng $g^{-1} / \mathrm{w}$. } \\
\hline \multicolumn{5}{|l|}{ b nd: not detected. } \\
\hline \multicolumn{5}{|c|}{ Median value recalculated from the data presented in Fermandes et al. 2008.} \\
\hline Mean of means calculated fror & ta presented in & aet al.. 2005. & & \\
\hline
\end{tabular}

